\title{
Sifting for salt strategies from the Sodium Working Group
}

Published at www.cmaj.ca on Oct. 7.

$\mathrm{I}$ t appears that Health Canada's Sodium Working Group, which was appointed two years ago to craft a national strategy to reduce Canadian salt consumption, is bogged down with matters of process and disagreements over what, if anything, should be done to limit sodium consumption.

But cochairs Hasan Hutchinson and Mary L'Abbe say they can't comment about whether the group is in disarray because of internal conflicts, or about what they think the group has achieved to date, until they get a green light from Prime Minister Stephen Harper's Privy Council Office.

"The questions will have to be submitted to PCO [Privy Council Office] via Health Canada for approval and to formulate the answers," says Hutchinson, director general of Nutrition Policy and Promotion for Health Canada.

Meanwhile, Health Canada spokesman Phillipe Laroche insisted in an email that the group is fine-tuning "a Canadian approach to dietary sodium reduction, including targets, an education/awareness strategy and a research agenda for consideration by the SWG [Sodium Working Group] this fall."

That's hardly progress, says Dr. Peter Magner, associate professor of medicine and head of the division of nephrology at the Ottawa Hospital and University of Ottawa in Ontario. "I would have hoped that there would be some concrete steps rather than just having two years later decided on a process that will start to be unveiled."

"It actually sounds like it's still the pussy-footing around 18 months later," he adds. "We should move quickly to start. It would be nice to see some public announcement of guidelines and targets and timelines. That's what one would like to ask of them: Where are their targets? Where are their timelines? And then what are the mechanisms you're going to use to achieve them."

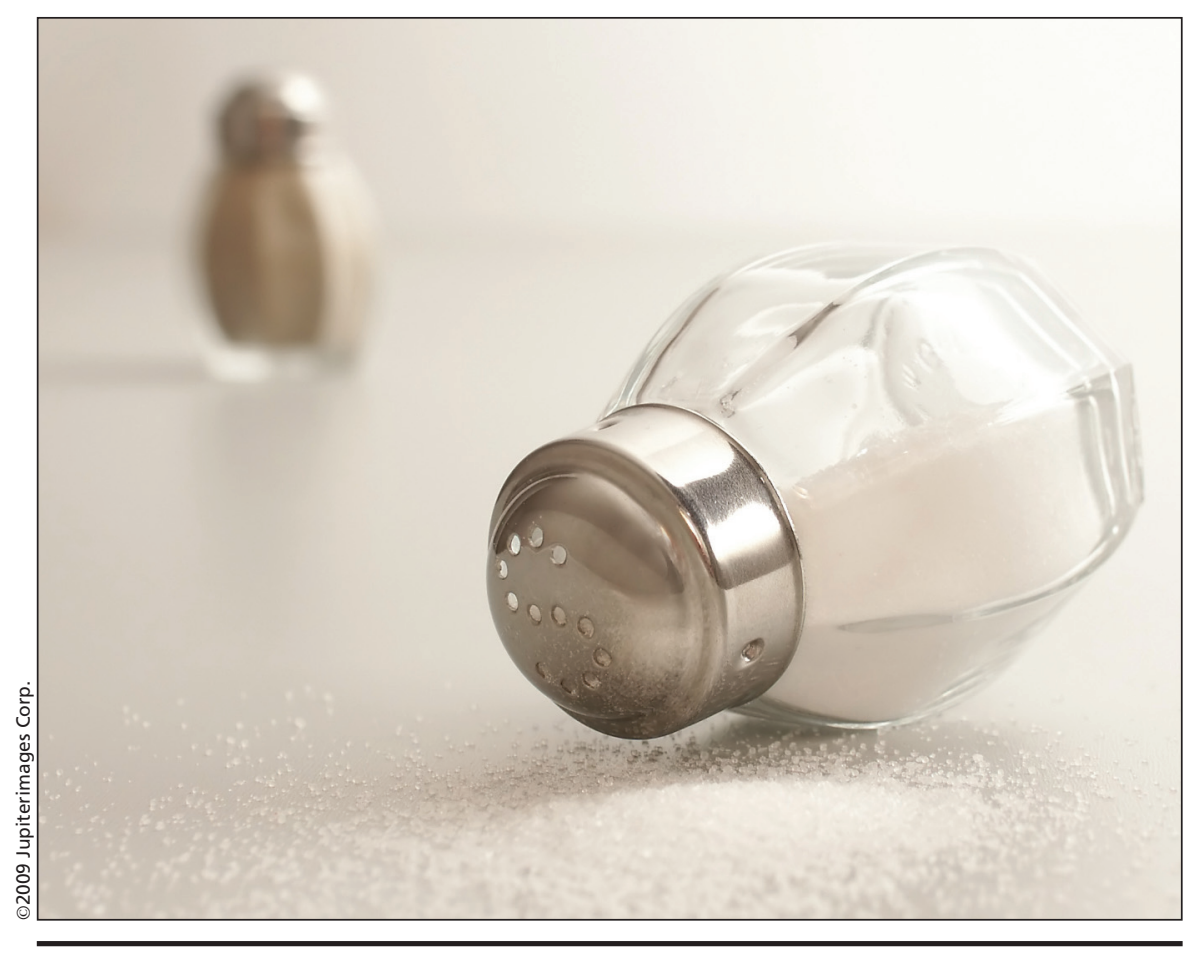

Blood Pressure Canada estimates that the average Canadian consumes roughly 3500 $\mathrm{mg}$ of sodium per day, much more than the recommended $1200 \mathrm{mg}$.

Former federal health minister Tony Clement established the working group in 2007, touting it as a "major step in helping Canadians improve their health," particularly in the reduction of cardiovascular diseases. Blood Pressure Canada estimates that the average Canadian consumes roughly $3500 \mathrm{mg}$ of sodium per day, much more than the recommended $1200 \mathrm{mg}$.

Yet, two years later, little has emerged from the working group. One member privately says it is "at loggerheads. We're at a total impasse."

But Blaise Ouattara, technical director of the Canadian Meat Council, who attended a Sept. 11 session in which the working group updated industry stakeholders about what it has learned and what other countries are doing to reduce dietary sodium, says such differences of opinion aren't unusual.

"I think it's normal because the issues facing the meat industry are not necessarily those facing the milk or vegetable industry. So it's normal that there are some differences in point of view," Ouattara says. "If you take the meat industry and the vegetable industry and you take the milk industry, there are different issues. The reason for using salt in different products is not the same. Sometimes it's used for food safety issues. Salt is something we use in the meat industry to control bacterial growth in different products, so if you reduce the salt you have to find a good replacement to be able to still control bacterial growth in your product."

An indirect glimpse into the working group's deliberations emerged in a document it issued in February, Stakeholder and Expert Perspectives on Dietary Sodium Reduction in Canada, which stated that "overall enthusiasm for sodium alternatives is not high."

The document also noted that nearly half of industry submissions dismissed sodium alternatives "not least because 
they do not yet offer replacements for the functional roles salt plays." The report also stated that "support for mandatory sodium reduction targets is concentrated among health and disease groups as well as health professionals. Industry feels strongly that targets should be voluntary."

Magner surmises industry groups are trying to thwart progress. "My bias is that I bet voluntary guidelines aren't going to be followed anyway, so I think it will end up being useless unless there's some legislation, but that's clearly not what the Harper government is going to do. It seems that industry has a large voice, and while paying lip service to the issue, may really be trying to block the process. To me it is not clear who will end up driving the agenda."

Yet, some working group members remain hopeful that a national saltreduction strategy will emerge.

"There's a diversity of interests and with all of these consultations that I've seen and participated in the past, on this issue and other issues, all of the constituency groups argue their positions on their hind legs. In the end, I expect it is a forum in which facts and arguments will matter and not parochial interest groups," says Bill Jeffery, national coordinator of the Centre for Science in the Public Interest, which recently released a report, Salty to a Fault, which indicated that there are wide variations in the sodium levels among groups of comparable foods (http://cspinet.org/ canada/pdf/saltytoafault.sept2009.pdf).

Laroche is confident that a strategy will emerge this year. "Since the main contributors to dietary sodium intake in the diets of Canadians are commercially prepared foods, it is recognized that a major focus of intervention to reduce sodium intakes will be on the reduction/removal of sodium from these foods. The working group will be meeting again with industry and stake- holders this fall to discuss a Canadian approach to dietary sodium reduction, and hopes to have a recommended strategy for moving forward on this issue by the end of 2010," he wrote in an email.

Jeffrey fears that once a strategy emerges from the working group, it may go the way of similar recommendations on trans fats - largely ignored, unimplemented and gathering dust. "I was quite disappointed that the trans fat task force recommendations that were made more than three years ago now haven't been implemented. Health Canada has already missed a self-imposed deadline for the ultimatum it gave to the food industry to reduce the amount of trans fats to acceptable levels or face regulations. That deadline passed in June and Health Canada hasn't even released the most recent round of monitoring data." - Becky Rynor, Ottawa, Ont.

DOI:10.1503/cmaj.109-3067 